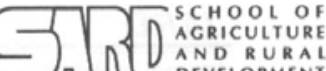
ANDRURAI DEVELOPMENT কৃষि ও পब্লী উন্ময়ন অনুষদ
Available online at http:/ / www.banglajol.info/index.php/jard
$\mathrm{J}$ ARD

Journal of Agriculture \& Rural Development

\title{
Effects of Youth Empowerment Strategies on Conflict Resolutions in the Niger-Delta of Nigeria: Evidence from Cross River State
}

\author{
N. I. OFEM ${ }^{1 *} \&$ A. R. AJAYI ${ }^{2}$ \\ ${ }^{1}$ Department of Agricultural Economics/Extension, Faculty of Agriculture, University of Calabar, \\ P.M.B. 1115, Calabar, Cross River State, Nigeria \\ ${ }^{2}$ Department of Agricultural Extension, Faculty of Agriculture, University of Nigeria, Nsukka
}

\begin{abstract}
The Niger Delta region of Nigeria has been ridden by youth restiveness and yet several intervention program have not yielded positive results. The study, therefore, evaluates the impact of youth empowerment strategies on conflict resolution using an ordered probit regression model. The study reveals that youth educational programs, provision of infrastructures and credit facilities showed significant effects as tools for conflict resolution. Employment opportunities and income indicated positive results yet they were not significant. This indicates that youth empowerment strategies must be sustainable if they have to make reasonable impact on conflict management.
\end{abstract}

Key words: Conflicts, empowerment, resolutions, strategies, youth, Niger-Delta.

\section{BACKGROUNDS}

Over time, the roles of the youth in national development have been acknowledged (Akpabio, 2005; Ajayi, 2006 and Gobeli, 1995). As they continue to play pervasive roles in nation building, the youth by definition have been regarded as that segment of the population from 18-35 years (National Policy of Youth Development, 1999) who are characteristically active, vibrant, daring and with useful energies. The development of the Nigerian nation from pre-colonial to independent and postindependent era has been attributed to vital contribution of the youth. Despite their positive roles in national development, they constitute the most critical and volatile segment of the society. The worsening economic situation in Nigeria from the austere periods to the SAP and Post-SAP era has threatened the collective psyche of the youth. General unemployment, lack of consistent policy framework for youth development, general economic hardship among others have thrown the youth into joblessness, agents of social vices and general idleness. As their conditions worsen, they have been used as agents of political thuggery and general misadventure. Moreover, they have become the major agents in social conflicts with diverse and devastating consequences in the nation. As their negative and pervasive roles continue to impact on the economy, several strategies of youth empowerment have been evolved over time. The strategies have, however, yielded little or no results as their activities have consistently imposed serious threats to social security, truncated economic activities and severe drainage of national income. The study, therefore, is aimed at identifying the causes of youth restiveness, the strategies of youth empowerment and the effects of these strategies on conflicts resolutions in the Niger-Delta.

* Corresponding author: Nneoyi I. Ofem, Faculty of Agriculture, University of Calabar, Nigeria, E-mail: ofeminas@yahoo.com

(C) 2008 School of Agriculture and Rural Development, Bangladesh Open University, All rights reserved. 


\section{Youth, Conflicts and Resource Endowments: A Framework}

The issues of youth restiveness, arm insurgence and resources endowment have attracted considerable interest in social and economic literature. The World Bank (2003) has reported that there seem to be strong correlation between outbreak of armed conflict and a country's dependence on one or two readily exploitable natural resources. At the same time, the presence of profitable resources was also reported as a factor in the spread of high level corruption, a further source of conflict and public resentment. Hence, critical assumptions have emerged that the very presence of valuable natural resources often serves as a "curse" that generates conflicts and that insurgent forces (e.g. youth) are frequently motivated by less genuine grievances than by "greed" for money from the control of national wealth. The curse element and greed element of natural resources endowment though as simplistic as they may seem are further exacerbated by the processes of bad governance regarded as the bad stewardship of resources (African Renewal, 2007).

The African Renewal (2007) also argues that the "greed versus grievance" view of conflict is a distortion as it tends to overemphasize the influence of natural resources on the behavior of insurgent groups and draw insufficient attention to how poor government management of resources can contribute to conflict and human rights. Furthermore, Folarin (2007) also reported that resource abundance may also cause conflict and this may occur when there is no motivation to innovate or diversify the economy, especially when the resources are readily available and are easily directly sold and as such there is a reluctance to invest in manufacturing or services and all capital is drawn to the abundance resources (Edu, 2007).

Akpabio (2005) also noted that the potential for quick profit by the main actors in naturally well endowed states and which can undercut the potential for good governance and set in motion vicious aspect of underdevelopment and a consequent recourse to armed conflict. The author highlighted the conflict process of some areas to include areas with which have experienced violent conflict in the preceding 10 years (a violent conflict is assumed to have at least 25 battle-related deaths per year), areas with low per capita Gross National Income (GNI) (that is less than US \$ 745 , countries with high level dependence on primary commodities export as share of the GDP, areas with endemic political instability, predicated on:

a) Constant changes in government structures in les than three years.

b) Lack of democratic accountability.

c) High level of internal violence and breakdown of law and order.

d) Restricted civil liberties and political rights, countries with high defense budgets (4\% or more of the $\mathrm{GNI}$ ) and internal arms proliferation, areas with high youth unemployment level (typically $10 \%$ or more of youth population). As frustrated youth are prime recruitment targets of militant protagonists and areas with endemic problems of ethnic dominance leading to the exclusion of minorities among others. However, Bihis-Tolentino (1995) and Onyekpe (2007) highlighted the characteristics of youth which influences their activism to include their search for avenues to direct their energies ways to be productive, receptiveness to new ideas; optimism for the future, boundless spirit, eagerness to learn, dynamism, and youthfulness. If these energies are not properly harnessed, they are invested in the wrong direction as is the case in the Niger Delta of Nigeria.

\section{METHODOLOGY}

The study was carried out in the Niger-Delta Region of Nigeria. The area consists of majorly nine states namely Abia, Akwa Ibom, Bayelsa, Cross River, Delta, Edo, Imo, Ondo and River states, respectively. The area is synonymous to oil production and exploitation in Nigeria. The core NigerDelta was previously limited to a few states in the South-South geo-political zone that is Rivers, Bayelsa, Akwa Ibom, Cross River, Delta and Abia States with commercial oil reserves and rivers which empty themselves into the Atlantic Ocean (Ekpo, 2004). The area is characterized by excessive oil exploration activities with severe impact on the environment and the ecosystems. Folarin (2007) and Edu (2007) have highlighted the extent of damage to the environment of the region occasioned by oil and gas exploration.

The area is generally regarded as the "hotbed" of crises in Nigeria. Brieger et al. (2004) reported that crises in the areas are caused by perceived destruction of agricultural resources, e.g. land and 
water or displacement of people from productive lands without adequate or commensurate compensations. Moreover, the authors traced the evolution of conflicts on the Niger Delta as those that involved youth restiveness from 1960-1990s, which is a reaction to injustice on the distribution of oil wealth. And often to severe environmental pollution. From 2000-2001, youth rebellion which evolved into criminal violence by militias, syndicates and cults. They also reported cases of fast growth of cult groups, thug armies raised by politicians and oil bunkerers who instigated violence during the 2003-2004 elections. The authors noted that 2004 to 2007 presupposes an arm race among politicians with oil bunkering gaining a better foot hold if effective measures are not put in place. Hence, in the study, a multi-stage sampling technique was used. Cross River State, an oil producing state with enormous agricultural resources which are currently under exploitation with its attendant crises was randomly sampled among the six oil producing states. The state has three (3) agricultural zones and senatorial districts. Hence, the Calabar agricultural zone within the southern senatorial district was purposively sampled as oil production and exploitation of agricultural resources are intense in this zone. The zone has seven (7) local governments; Bakassi, Akpabuyo, Calabar Municipality, Calabar South, Odukpani, Biase and Akamkpa from where Odukpani and Calabar South Local Governments were randomly sampled for the study. Another stage of sampling was the selection of communities for the study. In Odukpani five communities were randomly sampled such as Eniong, Adiabo/Efut, Ikoneto, Creek town 1, and Odot while in Calabar South Local Government five wards, ward 10, ward 18, ward 1 , ward 5 and ward 6 were randomly sampled. Twenty youth within the ages of 18-30 were randomly sampled and interviewed. From the ten (10) communities a total of 200 youths were identified and used for the study. Three government agencies were used for the study; State Ministry of Youth Development and Departments of Youth Development in the two Local Governments. 10 respondents were sampled from each of the agencies, a total of 30 government officials were used as respondents. Two sets of questionnaires were developed. One for the youth and another set for government officials to identify the youth empowerment strategies put in place by the State Ministry of Youth Development and Department of youth in the Local Government Councils. The instruments were validated and a reliability coefficient of 0.83 was computed which indicated that they were reliable. Data obtained were presented and analyzed using descriptive statistics such as frequencies, means and percentages. One null hypothesis was tested using a probit model to determine if indeed youth empowerment strategies have any significant effect on conflict resolution.

\section{Model specification}

Since the dependent variable of main interest effects of youth empowerment strategies on conflict management had an ordinal categorical nature, the ordered probit model (Damisa and Yohanna, 2007) was employed for the analysis of the polychotomous response data. Considering the ordinal probit model, let

$$
Y=\beta^{1} X_{1}+e_{1}
$$

Where $Y$ is the underlying latent variable that shows the degree of conflict management in a given youth empowerment strategy scenario. $X$ is a vector of parameters to be estimated, and $e_{1}$ is the stochastic error term. The latent variable exhibits itself in ordinal categories which were coded as $0,1,2,3, \ldots \ldots . K$. The response of category $\mathrm{K}$ is thus observed when the underlying conditions response falls in the K-th interval as:

$$
\begin{array}{lll}
Y^{0}=0, & \text { if } & Y^{0} \leq \delta_{0} \\
Y^{1}=1, & \text { if } & \delta_{0}<Y^{1} \leq \delta_{1} \\
Y^{2}=2, & \text { if } & \delta_{1}<Y^{2} \leq \delta_{2} \\
Y^{3}=3, & \text { if } & \delta_{2}<Y^{3} \leq \delta_{3}
\end{array}
$$

Where $Y(I=0,1,2,3)$ are the observable threshold parameters that will be estimated together with other parameters in the model. $\delta$ is normalized to a zero value and hence only $\mathrm{K}^{-1}$ additional parameters are estimated. The probabilities for each of the observed ordinal response which in this study had 10 responses $(0,1,2,3)$ will be given as:

$$
\begin{aligned}
& \text { Prob }(Y=0)=P\left(Y^{0} \leq 0\right)=P\left(\beta^{1} X+\sum_{1} \leq 0\right)=\varnothing\left(-B^{1} X\right) \\
& \text { Prob }(Y=1)=\varnothing\left(\delta_{1}-\beta^{1} X\right)-\varnothing\left(-B^{1} X\right) \\
& \text { Prob }(Y=2)=\varnothing\left(\delta_{2}-\beta^{1} X\right)-\varnothing\left(\delta_{1}-B X\right) \\
& \text { Prob }(Y=3)=1-\varnothing\left(\delta_{2}-\beta^{1} X\right)
\end{aligned}
$$


Where $0<\delta_{1}<\delta_{2}<_{i i i}<_{K-1}$ is the cumulative normal distribution function such that the sum total of the above probabilities is equal to one. The marginal effects of the regressors $X$ on the probabilities are not equal to the coefficients. The marginal probabilities could therefore be calculated from the probit model as:

$$
\frac{\mathrm{dprob}\left[Y_{k}\right]}{\delta X_{k}}=\left[\varnothing\left(\delta_{k-1}-\beta^{1} X_{k}\right)-\varnothing\left(\delta_{1}-\beta X_{1}\right)\right] \beta
$$

$\delta X_{k}$

Where $\varnothing \beta^{1} X_{k}$ is the normal density function $Y_{k} \delta_{k}$ the threshold parameter, and $X_{k}$ the K-th explanatory variable. The marginal effect was computed directly from the LIMDEP software employed in the analysis of the study.

The dependent variables indicated the level of conflict resolution in the area of study as low, medium or high. The values are 1 if low, 2 if medium, 3 if high and 0 otherwise.

The explanatory variables specified in the probit model as determinants of youth empowerment are: Educational level attained, skill acquisition, participation in community development, availability of infrastructure in the area, employment opportunities, and income as well as current occupation. The variables are defined in table 1.

Table 1. Description of Explanatory Variables used in the Youth Empowerment and Conflict Resolution Model

\begin{tabular}{ll}
\hline Variable & \multicolumn{1}{c}{ Description } \\
\hline EDU & Value 1 if respondent had Primary Education, 2 if secondary, 3 if tertiary, 4 others \\
OCCUP & Value 1 if farmer, 2 if trader, 3 if unemployed, 4 apprentice \\
EMPLO & Employment Opportunities measured as 1 if available, 2 not available \\
INCOM & This is the disposable income of the youth measured in naira \\
AVINFRA & Availability of social amenities in the area; value 1 if low, 2 medium, 3 high and 4 otherwise \\
SKACQ & Skill acquired by the youth as 1 if he/she has a skill and 0 if he has no skill \\
CRED & Access to credit measured as 1 if they have access and 0 if no access \\
\hline
\end{tabular}

Table 2. Nature of Conflicts in the Niger Delta

\begin{tabular}{|c|c|c|c|}
\hline & Areas/Groups Involved & Nature of Conflict & Basis of Conflict \\
\hline 1. & Oku Iboku (In Itu L.G.A. AKS.) & Inter-state Boundary Dispute & Economic Resources \\
\hline 2. & $\begin{array}{l}\text { Usung Esuk (In Odukpani } \\
\text { L.G.a. CRS) }\end{array}$ & Inter-state Dispute & Economic Resources \\
\hline 3. & Eleme & Communal Conflict & $\begin{array}{l}\text { Boundary ownership of benefits from oil } \\
\text { refinery and petrochemical producing state }\end{array}$ \\
\hline 4. & Okrika & Communal Conflict & \\
\hline 5. & Itsekiri & Ethnic Conflict & \\
\hline 6. & Urhoba & Ethnic Conflict & \\
\hline 7. & ljaw & Ethnic Conflict & Political Supremacy in Warri \\
\hline
\end{tabular}

Source: Brieger et al. (2004)

Table 3. Evolution of Conflict in the Niger Delta

\begin{tabular}{llc}
\hline Violence Process & \multicolumn{1}{c}{ Nature } & Sequence \\
\hline Youth Restiveness & Reaction to Injustice & $1960-1990$ \\
Youth Rebellion & & $1960-1990$ \\
Criminal Violence Militias, Syndicates and Cults & Instigation by Politicians & $2000-2004$ \\
Arms Race Among Warlords & Self Sustained & $2000-2007$ \\
\hline
\end{tabular}

Source: Briegar et al. (2004)

\section{RESULTS AND DISCUSSION}

\section{Socio-economic characteristics of youth}

The results shows the socio-economic characteristics of youth in Table 4. About 84 respondents interviewed were female representing $37.75 \%$ while 108 respondents representing $56.25 \%$ were male. This presupposes that youth volatility is common among the male youth who more often than 
not incite the females into violence. The table also shows the age brackets of the respondents as those between $15-20$ years (86) representing $44.79 \%$, $21-25$ years (42) that is $21.88 \%$, $26-30$ years (16) indicating $08.33 \%, 31-35 y$ ears (24) representing $12.5 \%$. This shows that the youth are relatively young in age (Bihus-Tolentino, 1995) and need be targeted if youth restiveness must be stemmed. Moreover, the table shows that about 96 respondents that is $50 \%$ had primary school education, 36 $(18.75 \%)$ had secondary education and $51(26.56 \%)$ had tertiary education. This imply that the bulk of the respondents interviewed had only primary education and youth restiveness could be a function of low educational attainment, dropping off from schools and graduate unemployment. The survey results also show that 42 respondents representing $21.88 \%$ are farmers, and only seven representing $3.65 \%$, are traders with about 21 representing $10.94 \%$ involved in artisan while a whooping 86 that is $44.79 \%$ are unemployed and about $36(18.75 \%)$ being self-employed. The data indicates why youth restiveness is a common phenomenon in the study area manifesting itself through "areaboyism", armed robbery, political thuggery, drug abuse and other social vices. The majority of the respondents are not actively and sustainable engaged thus predisposing them to violent tendencies.

\section{Table 4. Socio-Economic Characteristics of Youth}

\begin{tabular}{|c|c|c|c|}
\hline & Variable & Frequency & $\%$ \\
\hline \multirow[t]{4}{*}{ a) } & Sex: & & \\
\hline & Male & 084 & 37.75 \\
\hline & Female & 108 & 62.25 \\
\hline & & $\overline{192}$ & $\overline{100.00}$ \\
\hline \multirow[t]{7}{*}{ b) } & Age: & & \\
\hline & 1. $15-20$ & 86 & 44.79 \\
\hline & 2. $21-25$ & 42 & 21.88 \\
\hline & 3. $26-30$ & 16 & 08.33 \\
\hline & 4. $31-35$ & 24 & 12.50 \\
\hline & 5. $36>$ & 24 & 12.50 \\
\hline & Total & 192 & $\frac{12.00}{100.00}$ \\
\hline \multirow[t]{6}{*}{ c) } & Educational Level Attained & & \\
\hline & i. Primary School & 96 & 50.00 \\
\hline & ii. Secondary School & 36 & 18.75 \\
\hline & iii. Tertiary & 51 & 26.56 \\
\hline & iv. Others & $\underline{09}$ & 04.69 \\
\hline & Total & $\overline{192}$ & $\overline{100.00}$ \\
\hline \multirow[t]{7}{*}{ d) } & Occupation & & \\
\hline & i. Farmer & 42 & 21.88 \\
\hline & ii. Trader & 07 & 03.65 \\
\hline & iii. Artisan & 21 & 10.94 \\
\hline & iv. Unemployed & 86 & 44.79 \\
\hline & v. Self-employed & $\underline{36}$ & 18.75 \\
\hline & Total & $\overline{192}$ & 100.00 \\
\hline \multirow[t]{4}{*}{ e) } & Registered with Government Skill Acquisition Program & & \\
\hline & Yes & 86 & 44.79 \\
\hline & No & 106 & 55.21 \\
\hline & Total & $\overline{192}$ & 100.00 \\
\hline \multirow[t]{4}{*}{ f) } & Access to Credit from Government & & \\
\hline & Yes & 51 & 26.56 \\
\hline & No & 141 & 73.44 \\
\hline & Total & 192 & 100.00 \\
\hline \multirow[t]{4}{*}{ g) } & Under any form of Government Assistance & & \\
\hline & Yes & 62 & 32.29 \\
\hline & No & 130 & 67.71 \\
\hline & Total & 192 & 100.00 \\
\hline \multirow[t]{7}{*}{ h) } & Form of Government Assistance in Progress & & \\
\hline & i. $\quad$ Skill acquisition & 72 & 37.5 \\
\hline & Scholarship & 31 & 16.15 \\
\hline & Contract Employment & & \\
\hline & Sports Development & 08 & 04.17 \\
\hline & None & & \\
\hline & & $\begin{array}{r}15 \\
66 \\
192\end{array}$ & $\begin{array}{r}07.81 \\
34.38 \\
100.00\end{array}$ \\
\hline
\end{tabular}

Source: Field Survey, 2007. N = 192 
Furthermore, the table shows the number of youths who are registered with governments for skill acquisition programs hence only 86 representing $44.79 \%$ are registered while 106 representing $55.2 \%$ are not registered. Also only very few youths have access to credit that is $26.56 \%$ just as only 62 representing $32 \%$ are under any form of government assistance.

Finally, the table shows the forms of government assistance for youth empowerment such as skill acquisition $37.5 \%$, scholarship program $16.15 \%$, contract employments $4.17 \%$ and sports development $34.38 \%$. These results confirm the fact that youth empowerment programs in the study area are through skills acquisition, provision of credit, youth employment among others, they have not been effective as youth development strategies.

\section{Causes of youth restiveness}

The survey identified the various causes of youth restiveness and Table 5 shows that basic issues like lack of humanitarian and social welfare $(95.8 \%)$, problems of good governance in the NigerDelta $(94.8 \%)$, corrupt practices of government officials $(94.3 \%)$, inadequate training program for youth $(94.3 \%)$, and the urge to satisfy basic needs (93.8\%) are key issues identified as the reasons for incessant youth restiveness in the study area. These findings are, however, in line with the report of Brieger et al. (2004). Other issues also identified by the study are: the high cost of living (88.5\%), lack of self-esteem among the youths (83.9\%), lack of participation in community services and decision making (84.9\%). Furthermore, the table reveals that unemployment $(79.2 \%)$, inadequate recreational facilities $(73.9 \%)$, lack of quality education among the youth $(79.2 \%)$ and lack of economic support systems $(73.9 \%)$ are all predisposing factors for youth restiveness.

\section{Table 5. Causes of Youth Restiveness}

\begin{tabular}{clcc}
\hline & Causes of Youth Restiveness & Frequency & $\%$ \\
\hline i. & Inadequate communication and understanding with parents & 101 & 52.6 \\
ii. & Drug Abuse & 96 & 50.0 \\
iii. & Lack of Employment & 152 & 79.2 \\
iv. & Inadequate Recreational Facilities & 142 & 73.9 \\
v. & High Cost of Living & 170 & 88.5 \\
vi. & Need for Training Programs & 181 & 94.3 \\
vii. & Need to satisfy Basic needs & 180 & 93.8 \\
viii. & Lack of Education & 152 & 79.2 \\
ix. & Lack of Self-Esteem & 161 & 83.9 \\
x. & Lack of Economic Support Activities & 142 & 73.9 \\
xi. & Lack of Participation in Community Decision Making & 163 & 84.9 \\
xii. & Corrupt Practices of Government Officials & 181 & 94.3 \\
xiii. & Greed on the part of the Youth & 84 & 43.8 \\
xiv. & Lack of Good Governance & 182 & 94.8 \\
xv. & Lack of Humanitarian or Social Welfare Program & 184 & 95.8 \\
\hline
\end{tabular}

Source: Field Survey 2007. $\mathrm{N}=200, \mathrm{n}=192$

\section{Youth empowerment strategies}

The study identifies the nature of youth empowerment strategies put in place by the various governments at the State and Local Government levels, respectively. Table 6 shows that formation of youth organizations ( $80 \%)$ and opportunities for physical, social and mental development $(70 \%)$ have been provided to the youth by state and local governments. Respondents from the statutory agencies of governments for youth development also points to the fact that they have provided for the development of youth skills $(33.3 \%)$, better working opportunities $(20.0 \%)$, active participation in community service $(36.7 \%)$ and provision of micro-credit facilities. The results confirm the reports of the Cross River State Economic Empowerment and Development Strategy Document - CR-SEED (2005). Moreover, the study reveals that recreational facilities (46.7\%), leadership training program $(66.7 \%)$ and regular scholarship/bursary program for youth in educational institutional have been provided as youth empowerment schemes. 
Table 6: Youth Empowerment Strategies

\begin{tabular}{clcc}
\hline & Youth Empowerment Strategies & Frequency & $\%$ \\
\hline i. & Development of Youth Skills & 10 & 33.3 \\
ii. & Opportunities for Physical, social and mental development & 21 & 70.0 \\
iii. & Provision of better working opportunities & 06 & 20.0 \\
iv. & Active Participation in Community Service & 11 & 36.7 \\
v. Provision of Recreational Facilities & 14 & 46.7 \\
vi. Involvements in Leadership Training & 20 & 66.7 \\
vii. Provision of Micro credit facilities & 09 & 30.0 \\
Viii. Regular Scholarship/Bursary & 11 & 36.7 \\
ix. $\quad$ Formation of Youth Organization & 24 & 80.0 \\
x. Involvement in Decision Making Processes & 15 & 50.0 \\
\hline
\end{tabular}

Source: Field Survey $\quad \mathrm{N}=30$

\section{Test of hypothesis}

The results of the maximum likelihood estimates of the probit model are presented in Table 7 . The results indicate that the chi-square value was significant at $1 \%$ indicating that the model gave a good-fit. As noted by Hussain, Byerlee and Heisey, (1994), there is no standard goodness of fit tests for logit, probit and Tobit models; therefore, the chi-square statistics is computed to test the joint effects of the independent variables. The results indicate that education (EDU) has a positive relationship with conflict resolution and is significant at $5 \%$ indicating that the provision of quality education could help stem youth restiveness and conflicts in the area. Moreover, occupation (OCCUP), employment (EMPLO) and income (INCOM) indicated positive relationships but were not significant. This shows that the provision of employment and occupational opportunities and the income accruing to youth are not sufficient conditions to resolve conflicts if the variables are not sustainable themselves to cater for the needs of the youth. Furthermore, availability of infrastructure (AVINFRA) showed a positive and significant relationship, implying that the provision of infrastructural facilities within the area can significantly reduce the spate of youth restiveness. The provision of credit facilities (CREDT) to youth showed a significant but negative relationship between youth empowerment and conflict resolution. Also implying that credit provision to youth may not be a sufficient condition for crisis resolution among the youth especially, when it is not sustained. Finally, skill acquisition (SKACQ) showed positive but insignificant results indicating that skill acquisition could positively influence youth restiveness but the strategy has not been sustained in the study area.

Table 7. Maximum Likelihood Estimates of the Probit Model

\begin{tabular}{lcc}
\hline \multicolumn{1}{c}{ Parameters } & Coefficient & t-values \\
\hline Constant & $5.446^{\star *}$ & 2.956 \\
EDU & 0.572 & 1.252 \\
OCCUP & 0.881 & 1.387 \\
EMPLO & 0.143 & 1.149 \\
INCOM & 1.672 & 2.154 \\
AVINERA & $0.532^{\star *}$ & 1.729 \\
SKACQ & 0.431 & 1.156 \\
CREDT & $0.721^{* *}$ & -1.138 \\
Chi-square R & $0.72^{*}$ & \\
Sample Size & 192 & \\
\hline
\end{tabular}

Note: significance level: *** $10 \%,{ }^{* *}$ for $5 \%$ and ${ }^{*}$ for $1 \%$

\section{Conclusion and recommendations}

Youth empowerment strategies in the restive states of the Niger-Delta have been designed to reduce conflict associated with youth. However, the strategies introduced have not been sustained and they have been marred by political considerations, inconsistencies in policies and lack of a proper framework for youth development. However, the study has shown that a proper youth empowerment framework can effectively engage the youth, "mind, soul and body" thereby 
distracting attention to current issues that results to youth restiveness. Therefore, the study recommends the following:

* There should be a deliberate policy by relevant development agencies to meaningful target the youth in the Niger-Delta.

* Youth employment, and occupational opportunities provided to youth should be that which are sustainable and would make meaningful and lasting impact on them.

* The provision of good governance structures that is transparent and accountable is necessary to stem the issues of conflict in the Niger Delta.

* Skill acquisition programs should be emphasized in educational curriculum at all levels of educational training to help many youth development program.

Finally, the impact of the Niger-Delta Development Commission (NDDC) program on youth development vis-à-vis conflict management should be evaluated.

\section{LITERATURE CITED}

Akpabio, I. 2005. "Human Agriculture Social Themes in Agricultural Development". Abaam publishing Co., Uyo.

Akali, K. N. 2007. The contribution of environmental rights action (ERA) in the struggle for ecological right in the Niger-Delta. The Constitution 7(1), 23-36.

Ajayi A. R. 2006."A Guide for Young Farmer Clubs Programme”. SAC Impressions, Akure.

African Renewal. 2007. Conflict resources from "Curse" to blessing: Transforming an African war risk into a peace asset. UN Dept Public Inf 20(4), 17-21.

Bihis-Tolentino, J. (1995). Institutional strengthening and programme management related to rural youth programmes. In "Expert Consultation to Extension Rural Youth Programme and Sustainable Development", Food and Agriculture organization Rome. pp. 109-122.

Briegar, W. R., Albert, I., Achike, A. and Schwenthe, S. (Edited) 2004. "Strategic Analysis of Development Constraints and Priorities for Action in Southern Nigeria: Updates on Agriculture and conflict". Management Systems International-USAID, Abuja and Washington DC.

Cross River State, 2005. "Cross River State Economic and Development Strategy (CR-SEED) Documen". Department of Economic Planning, Calabar.

Damisu, M. A. and Yohanna. 2007. Role of rural women in farm management decision making process: ordered probit analysis. World J Agric Sci 3(4), 543-546.

Edu, O. K. 2007. Ownership of oil and gas in Nigeria: Matters arising. The Constitution 7(1), 62-75.

Ekpo, U. 2004. "The Niger Delta and Oil Politics". International Energy Communications Ltd., Lagos.

Folarin, S. 2007. Niger-Delta Environment, Ogoni Crisis and the State. The Constitution 7(1), 37-61

Gobeli, V. C. 1995. "Youth Development, Part of a Comprehensive Strategy for Sustainable Development in Developing Countries". An Expert Consultation on Extension Rural Youth Programme and Sustainable Development, Food and Agricultural Organization, Rome. 65-78.

Hussain, S. S., Byerlee, D. and Heisey, P. W. 1994. Impacts of the training and visit extension systems on farmers knowledge and adoption of technology: Evidence from Pakinstan. Agric Econ 10, 39-47.

Onyekpe, N. 2007. Managing the youth at election. The Constitution 7(1), 76-87.

World Bank. 2003. World Development Report, 2002. World Bank, Washington DC. 